\title{
Surfaces
}

\section{RENAISSANCE - REBIRTH: SOME REMARKS ABOUT THE HUMANISTIC INTERPRETATION OF HISTORY}

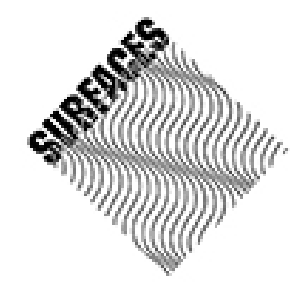

\section{Andreas Kablitz}

Volume 9, 2001

TROISIÈME CONGRÈS INTERNATIONAL SUR LE DISCOURS

HUMANISTE. LA RÉSISTANCE HUMANISTE AU DOGMATISME AUJOURD'HUI ET À LA FIN DU MOYEN ÂGE

THIRD INTERNATIONAL CONFERENCE ON HUMANISTIC DISCOURSE. HUMANISTIC RESISTANCE TO DOGMATISM TODAY

AND AT THE END OF THE MIDDLE AGES

URI : https://id.erudit.org/iderudit/1065068ar

DOI : https://doi.org/10.7202/1065068ar

Aller au sommaire du numéro

\section{Éditeur(s)}

Les Presses de l’Université de Montréal

ISSN

1188-2492 (imprimé)

1200-5320 (numérique)

Découvrir la revue

Citer cet article

Kablitz, A. (2001). RENAISSANCE - REBIRTH: SOME REMARKS ABOUT THE HUMANISTIC INTERPRETATION OF HISTORY. Surfaces, 9.

https://doi.org/10.7202/1065068ar
Résumé de l'article

L'auteur propose une interprétation historique de l'humanisme à travers une analyse de la notion de renaissance, concept clé, mais sous des dehors différents, tant pour l'interprétation que le XVIe siècle a fait de soi-même que de l'apparition, au cours du XIXe siècle, du terme « Renaissance " pour désigner une période historique. Cependant les contextes d'utilisation des mots rinascita chez Vasari et, plus tard, « Renaissance » chez Michelet diffèrent de façon marquée. Alors que chez Vasari, la renaissance implique une réinterprétation de la relation entre art et nature contre le jugement hérité du nominalisme à l'effet qu'il existe un nombre prédéterminé de possibilités, elle fait référence chez Michelet au développement des études empiriques de la nature et à la récupération du programme de l'Antiquité grecque et latine de possibilité pour l'humanité de constitution d'elle-même par le travail de la raison. Ainsi, le Moyen Âge, et particulièrement la scolastique, sont critiqués parce qu'ils gommaient la nature. La perte d'importance de l'art dans la conception de la Renaissance chez Michelet constitue une conséquence logique de son interprétation de cette période comme moment de rétablissement de la vérité. Au contraire, si l'art est au coeur de la conception de la rinascita chez Vasari, c'est parce que l'art comme création peut ouvrir toutes les possibilités et participe ainsi d'un effort vers la perfection.
Ce document est protégé par la loi sur le droit d'auteur. L'utilisation des services d’Érudit (y compris la reproduction) est assujettie à sa politique d'utilisation que vous pouvez consulter en ligne.

https://apropos.erudit.org/fr/usagers/politique-dutilisation/ 


\title{
RENAISSANCE - \\ REBIRTH: SOME \\ REMARKS ABOUT THE \\ HUMANISTIC \\ INTERPRETATION OF \\ HISTORY
}

Andreas Kablitz

Surfaces vol IX 101.8 (v1.0a - 15.12.2001) - ISSN:

1188-2492

Tout texte reste la propriété de son auteur. Néanmoins, SURFACES demande d'être citée à l'occasion de toute autre publication du texte en question.

\begin{abstract}
The author works towards a historical understanding of humanism through his analysis of the notion of rebirth which was a key concept, but under different guise, both in the self-interpretation of the sixteenth century as well as in the appearance, during the nineteenth century, of the term "Renaissance" when it was first used to describe a historical period. However, the contexts of Vasari's use of the word rinascita and later of Michelet's use of the word Renaissance differ greatly. Whereas in Vasari, rebirth is meant to reinterpret the relationship of art to nature against nominalism's views that there are preordained possibilities, in Michelet rebirth is meant to refer to the development of empirical studies of nature and the retrieval of the Greek and Latin program of self-constitution for mankind through the work of reason. Hence, the Middle Ages, and scholasticism especially, are blamed for their suppression of nature. The loss of the importance of art in Michelet's
\end{abstract}


conception of the Renaissance follows logically from the interpretation of this period as a reestablishment of truth. On the contrary, if art is of crucial importance in Vasari's conception of rinascita, it is because art as creation opens all possibilities and, thus, is part of an effort towards perfection.

\section{RÉSUMÉ}

L'auteur propose une interprétation historique de l'humanisme à travers une analyse de la notion de renaissance, concept clé, mais sous des dehors différents, tant pour l'interprétation que le XVIe siècle a fait de soi-même que de l'apparition, au cours du XIXe siècle, du terme « Renaissance » pour désigner une période historique. Cependant les contextes d'utilisation des mots rinascita chez Vasari et, plus tard, «Renaissance » chez Michelet diffèrent de façon marquée. Alors que chez Vasari, la renaissance implique une réinterprétation de la relation entre art et nature contre le jugement hérité du nominalisme à l'effet qu'il existe un nombre prédéterminé de possibilités, elle fait référence chez Michelet au développement des études empiriques de la nature et à la récupération du programme de l'Antiquité grecque et latine de possibilité pour l'humanité de constitution d'elle-même par le travail de la raison. Ainsi, le Moyen Âge, et particulièrement la scolastique, sont critiqués parce qu'ils gommaient la nature. La perte d'importance de l'art dans la conception de la Renaissance chez Michelet constitue une conséquence logique de son interprétation de cette période comme moment de rétablissement de la vérité. Au contraire, si l'art est au coeur de la conception de la rinascita chez Vasari, c'est parce que l'art comme création peut ouvrir toutes les possibilités et participe ainsi d'un effort vers la perfection.

This paper is an attempt to make a contribution to the third workshop of the "International Conference for Humanistic Discourses" from a historical point of view. The following reflections originate from the term 'humanism' itself, more precisely from a certain aspect of 
its use. This aspect could be called the - more or less latent - historical index of this term. For no matter what meaning it may have or which anthropology it may represent, the term 'humanism' always refers to a specific historical literary culture of the fifteenth and sixteenth century. This is more than a simple case of semantic polysemy. The polysemy inherent in the meaning of 'humanism' seems to be rather programmatic; it appears to be a strategy of selflegitimation by reference to the past. On the other hand, the latent or obvious reference to a historical literary culture can be described as one of the consequences of that "resistance to dogma" which, indeed, is typical for all conceptions of humanism. Nevertheless, "resistance to dogma" is rather characteristic of those forms of humanism that have been defined since the nineteenth century. But this formula is perhaps less suitable as a description of humanistic culture in the Early Modern Ages. Of course, humanists of that time were vehement critics of all scholasticism, and perhaps even of all logical reduction of the conditio humana. On the contrary, truth again became a question of authority, and such authority was ascribed in a large part to classical literature. Maybe the different approaches to ancient culture are among the most specific distinctions that can be drawn between nineteenth century humanism and the concept of humanism prevailing in the age that today is called the 'Renaissance'. The Renaissance humanists' interest in classical texts is based on an interest in their truth; the nineteenth century interest in classical literature is rather an aesthetic one. Thus, the idea of humanism conceived as a refusal of medieval tyranny, as a programmatic resistance to the clerical suppression of truth is one of the dogmata of the nineteenth century; and even today it has lost little of its attractiveness, but this is a certain form of the hermeneutic usurpation of an alien historical culture. Such usurpation raises the question of its function, and this function seems to consist of the establishment of a historical legitimacy. It is probably the Achilles heel of all programmatic resistance to dogma that can be discovered here. Even a programmatic propagation of intellectual freedom needs a mechanism of legitimation. Systematic legitimations, obviously, are not suitable for that purpose, and, therefore, the past becomes attractive for the foundation of legitimacy, in other words, for an avoidance of contingency. The propagation of intellectual freedom justifies itself by a reference to historical discourses of freedom. But, as we have seen, this strategy of selflegitimation ultimately involves the danger of an illegitimate usurpation of the past. The teleology of freedom constitutes a risk for an appropriate reading of 
the past and produces a form of 'hermeneutic emprisonement.'

It is a similar case of hermeneutic usurpation that I am going to consider in the following passages. More exactly, I will deal with the idea of rebirth, which belongs, indeed, to the central concepts of the historical self-interpretation of the sixteenth as well as nineteenth century humanists. This term again implies a program of self-legitimation that works with reference to the past. The advantage of using this term is obvious: The idea of rebirth provides an aura of vitality to an interpretation of reality, which ultimately is contingent. It confers to its own position an incontestability that seems to bring all discussions to a final term. When the nineteenth century historians coined the term 'Renaissance' to define the first period of modernity, they apparently aimed at an admittedly flattering - self-interpretation, which yet escapes all doubt. Using the term 'Renaissance', the act of interpretation itself was hidden in the unchallengeable naturalness of life - this presumed naturalness apparently being an effect of rhetoric.

The strategic potential of the term also relies upon the fact that it has to be regarded as a quotation. Indeed, fifteenth and sixteenth century authors use the word rinascita to interpret their own epoch. But their use of rinascita differs essentially from the meaning given to the term 'Renaissance' by nineteenth century historians. It is specifically this difference that will be considered in greater detail in the following pages; more precisely, I will attempt to confront two prominent texts, each of them being of major importance for the respective use of the term in both epochs. At first, we have to consider the Vite of Giorgio Vasari, to be more exact, the Preface of the biographies dedicated to famous artists of his time. There was no other author of his day who developed an equally systematic theory of rebirth. Hence, it was mainly the reception of Vasari's work that initiated the fascination with this term in the historical thought of the last century. But the definition of an Age of Renaissance only pretends to carry further Vasari's discussion on rinascita. The supposed quotation is, in fact, a kind of simulation, a simulation that is as much unintentional as it is useful. It is only a latent transformation of the original sense of rinascita that allows reference to the historical term itself. These transformations of rinascita will be focused on an interpretation of text that belongs to the most prominent texts on this topic of the nineteenth century. It was La Renaissance, a volume of the History of France written by Jules Michelet, that became the starting point for the use of the term in 
discussion. For this reason, the following considerations are also meant to be a contribution to the archeology of the term 'Renaissance' used as a name of a period, this meaning of the term being entirely unknown to the humanists of the Early Modern Ages. Their use of rinascita does not refer to a period, but to a certain moment, that is to say the moment representing the end of decline and the beginning of improvement. Strictly speaking, it is only this meaning of rebirth that makes sense. Rebirth as such can only be conceived as a moment. The archeology of the term 'Renaissance' is therefore also an attempt to account for the reasons of its semantic alienation.

As I mentioned above, Vasari dedicated his Vite to a series of famous contemporary artists. From that point of view, it is perfectly coherent to limit the concept of rebirth to art. But this restriction is everything but occasional. As I will try to demonstrate, the limitation of rebirth to art is due to the fact that the idea of rebirth is part of Vasari's specific concept of the arts. The theoretical framework of this concept is constituted by a debate that had been going on throughout the Middle Ages, the debate on the relation between art and creation. It was a specifically Christian discussion that, in a certain way, completed and replaced the ancient classical debate on the relation between art and nature. It is important to realize the medieval provenance of the questions discussed in Vasari's work, for their traditionality undermines in a certain way his claim for a rebirth, for an unconditional return to the origin: the interpretation of contemporary art as a form of rebirth perpetuates the premises of medieval thought; hence the premises of a thought that the humanists, indeed, considered to be a historical error and whose heritage they, therefore, rejected. Vasari certainly defines the relation between art and creation in a new way. Nevertheless, his outline of a history of art is still an attempt to define the specific relationship between both categories and to resolve the problems raised by it. The most common medieval concept that had been used to reconcile art and creation was a metaphorical concept that viewed the Creator as an artist, a concept that is also known under the heading deusartifex. This traditional metaphor claimed that there is a relation of analogy between art and creation. Vasari radicalized this 
analogy, replacing it by the identification of both. One of the most important consequences that arise from this radicalization of the traditional concept is the replacement of analogy by time: the figure of time supplants analogy and, consequently, the relation between art and creation becomes a historical one.

The effects of that transformation find their expression in Vasari's interest in the biblical myth of creation, in which he had to find the origin of all art. It seems to contradict our current idea of humanistic culture that, neglecting all classical authors, Vasari returns to the Old Testament and Genesis. Nevertheless, his summary of the myth of creation represents a rewriting. It is only on these conditions that this myth can tell the story of the origin of art.

Cosí, dunque, il primo modello onde uscí la prima immagine dell'uomo fu una massa di terra, e non senza cagione; perciocché il divino architetto del tempo e della natura, come perfettissimo, volle mostrare, nella imperfezione della materia, la via del levare e dell' aggiugnere; nel medesimo modo che sogliono fare i buoni scultori e pittori, i quali ne' lor modelli, aggiugnendo e levando, riducono le imperfette bozze a quel fine e perfezione che vogliono. Diedegli colore vivacissimo di carne; dove s'è tratto nelle pitture, poi, dalle miniere della terra, gli istessi colori, per contraffare tutte le cose che accaggiono nelle pitture. [ $\underline{\mathbf{1}}$ ]

One of the most salient properties of that transformation of the Old Testament's beginning is Vasari's use of the term modello, whose traditional meaning almost seems to be inverted. Modello no longer denotes an image or object that precedes the production of a work of art, it refers to the formless, bulky matter, from which the divine artist creates man and thus demonstrates his proper excellence. In particular, the meaning of modello in Vasari's description of creation denies the preexistence of an idea that constituted one of the most essential premises of the metaphor of deus artifex. As the artist finds in his mind the image of the work he wants to build, the creator also finds in his mind the ideae of all creatures. But, in Vasari, no trace of these ideas, preceding the act of creation, can be found. Vasari's withdrawal from such a conception can be seen as a result of an important transformation that philosophy had undergone in the later Middle Ages, a transformation that was due to the success of 
nominalism. Indeed, nominalism forbids assuming the existence of ideas conceived as metaphysical entities preceding the individual creatures, which are nothing but different representations of the original idea. The main argument set out by theology against the existence of such ideae was based on the concern for God's omnipotence, since the existence of these entities would illegitimately limit the creator's power. Vasari's answer to the transformation of the traditional conception of creation differs to a considerable extent from those answersthat were given by his predecessors. The specific characteristics of his theory of art become particularly manifest, if one compares them to Nicholas of Cusa's description of human art. He also took into account the changes in medieval thought caused by the rise of nominalism. As he declares, the universe can no longer be reduced to a limited number of ideas, but the number of these ideas has to be infinite. Nicholas had to concede the same infinity of ideas to the human mind. Man, now, becomes an alter deus, a claim that bears a considerable risk to the preservation of God's superiority. Abandoning completely the belief in the existence of ideas, Vasari significantly goes beyond Nicholas' claim for their infinite number. In Vasari's Vite, creation is an entirely contingent, autoreferential act of God, and God's creation is imitated by the human artist, for whom it becomes the only model. The replacement of an analogical relation between art and creation by a historical one obtains its plausibility from the transformation of medieval philosophy, but at the same time, this transformation is nothing more than a prerequisite for Vasari's specific solution of the problem raised by it .

The establishment of a historical relation between art and creation involves a deep risk for all human art, because time contains an unavoidable potential for destruction. The identification of the model with the origin implies a constantly increasing temporal distance between the divine model and human art. It implies the loss of presence of the model itself. Thus, history necessarily becomes a history of decline. Yet, Vasari's assumption of an unavoidable decay is accompanied by the idea of an inverse relation existing between time and art. It is the fact that, henceforth, creation itself is substantially related to timethat generates this idea. In this respect, it is of major importance that the traditional concept of art is now shaping the idea of the act of creation. The adaptation of that concept to the needs and procedures of an artist has considerable effects; it involves even the latent renouncement of one of the central assumptions of all Christian theory of creation, 
the assumption of the creatio ex nihilo. The conception of a world created out of nothing is necessarily contradicted by the idea of an artist who is gradually improving his work, for this world could not be anything but perfect from the very first moment of its existence. On the contrary, the idea of an artist successively improving his work is barely compatible with the implications of omnipotence. A creation regarded as manufacturing, as a gradual production, however, grants an important role to time, for time is a dimension of improvement. Thus, creation appears to be a model of perfecting objects of inferior quality. From that point of view, time belongs essentially to all art as one of its most important prerequisites.

The transfer of the techniques of perfection undoubtedly indispensable to all art - to the idea of creation conceived as a model of improvement also bears important consequences with regard to the status of nature. Nature can no longer be the definite result of creation. Nature even loses its traditional role and importance. It is no longer a mirror of God, but a document of its own fascinating production. As a consequence, the heritage of creation now passes to art.

The interpretation of time as a dimension of perfection must unavoidably conflict with the equally convincing interpretation of time as a decline. Actually, this contradiction plays an important part in Vasari's outline of the history of art from its mythical beginnings to its contemporary state. The resolution of the contradiction between the opposite concepts of time determines to a high degree the role of rinascita. Recurring to the idea of rebirth, Vasari succeeds in reconciling both parts of its twofold history of art, each representing the contradictory relations between time and art. The unavoidable loss of the origin is mirrored in the history of a decline finding its term in a real perversion of art in the Middle Ages. On the contrary, time conceived both as a prerequisite for and a dimension of artistic perfection is the law under which the second period of the development of human art is placed. That is to say from the fourteenth century to the present time of Vasari.

Consequently, Vasari's primary interest focuses on the construction of a history of decline during which man loses his original perfection. It is in the Roman Empire that the loss of man's initial excellence occurs. The cause of the decline is indicated, in particular, by Vasari stressing the fact that the beginning of this decay considerably precedes the barbarian's invasions. Finally, 
it is the effect of time and its inherent potential of annihilation that initiates the ruin of art.

The revision of traditional assumptions brought about by the establishment of a historical link between creation and art is especially revealed by one of the reasons that in Vasari's view, is responsible for the decline of art. In his view, the rise of Christian faith contributes considerably to that decay. The iconoclasm of the victorious Christians that was directed against the images of pagan Gods is presented by Vasari as one of the major causes underlying the decline of an art whose deterioration annihilates the heritage of creation.

Ma quello che sopra tutte le cose dette fu di perdita e danno infinitamente alle predette professioni, fu il fervente zelo della nuova religione cristiana, la quale, dopo lungo e sanguinoso comabttimento, avendo finalmente, con la copia de' miracoli e con la sinceritá delle operazioni, abattuta e annullata la vecchia fede de' gentili; mentreché ardentissimamente attendeva con ogni diligenza a levar via ed a stirpare in tutto ogni minima occasione donde poteva nascere errore, non guastò solamente 0 gettò per terra tutte le statue maravigliose, $\mathrm{e}$ le sculture, pitture, musaici, ed ornamenti $\mathrm{de}^{\prime}$ fallaci Dii de' gentili; ma le memorie ancora e gli onori d'infinite persone egregie, alle quali per gli eccellenti meriti loro dalla virtuosissima antichitá erano state poste in pubblico le statue e l'altre memorie. [...] Ed avvengaché la religione cristiana non facesse questo per odio che ella avesse con le virtú, ma solo per contumelia ed abbattimento degli Dii de' gentili; non fu però che da questo ardentissimo zelo non seguisse tanta rovina a queste onorate professioni, che non se ne perdesse in tutto la forma. [ $\underline{\mathbf{2}}$ ]

This judgement on the effects of the destruction of pagan art by the Christians causes a marginalization of the history of salvation. A definition of virtue that consists of artistic perfection reflects the substantial devaluation of Christian ideas, for it replaces the obedience to God's moral demands by a technical competence. It is this particular marginalization of the history of salvation and the emancipation of virtue from faith that are apt to explain the transfer of any idea of rebirth from moral virtue to art: to a conception of an art that preserves the heritage of creation. The transformation of the history of salvation into art results from the change undergone by 
the concept of creation. If interest is no longer centered on a world created by God, but on the process of its production, then the loss of artistic perfection, consequently, becomes more important than the violation of nature's order, for the simple reason that art preserves the heritage of creation, the dowry given to man by God. The prerequisites for the transfer of the notion of rebirth to artistic practices come to light here. The idea of rebirth, defined in St. John's Gospel as a prerequisite for moral redemption, henceforward represents the release from the steady decline of art. The radicality of this rewriting of the history of salvation is mirrored in the description of the destruction operated by the early Christians. Instead of being the first witnesses of the redemption with religious zeal, they contributed to the annihilation of art and hence to the deterioration of creation.

Despite the transformation that the concept of rebirth undergoes in this transfer from ethics to art, its mythical origin, however, remains visible.

E gli uomini di quei tempi non essendo usati a veder altra bontá né maggior perfezione nelle cose di quella che essi vedevano, si maravigliavano, e quello ancoraché baronesche fossero, nondimeno per le migliori apprendevano. Pur gli spiriti di coloro che nascevano, aitati in qualche luogo dalla sottilitá dell'aria, si purgarono tanto, che nel 1250 il cielo, a pietá mossosi dei begli ingegni che 'l terren toscano produceva ogni giorno, li ridusse alla forma primiera. E sebbene gli' innanzi a loro avevano veduto residui d'archi, o di colossi, o di statue, o pili, o colonne storiate, nell' etá che furono dopo i sacchi e le ruine e gl' incendi di Roma, e' non seppono mai valersene o cavarne profitto alcuno, sino al tempo detto di sopra. Gli ingegni che vennero poi, conoscendo assai bene il buono del cattivo, ed abbandonnando le maniere vecchie, ritornarono ad imitare le antiche con tutta l'industria ed ingegno loro. [ $\underline{\mathbf{3}}$ ]

The mythical dimension of rebirth is unmistakably taken seriously. Rebirth appears not only as an effect of a transcendent intervention but it also reveals the pity of God. Moreover, rebirth is considered a reward for good behaviour. The begli ingegni, born in Tuscany, are rewarded with rebirth for the first successes in their efforts to improve artistic production. This improvement is explicitly called 'purgation', and the mere use of this 
term once more demonstrates the presence of the 'old' traditional moral meaning within this new concept of rinascita.

Up to this point, we have predominantly discussed the conditions for this transfer of the idea of rebirth from ethics to art. The following discussion has to consider some of its effects or, to be more precise, it has to consider the difference between art after its rebirth and art at its origins. Rinascita, obviously, does not represent a repeatable event, and therefore it is not a simple return to the origin. The decisive difference between them is constituted by the fact that the rebirth of art is to a large extent identical with a change in the artist's attitude towards the past. Before the moment of rebirth, artists had 'to be blind'. Henceforward, they will be able to distinguish between good and evil. From that point of view, the decline of art coincides with the artist's incapacity to use the resources of tradition. Rebirth, in a certain sense, marks the beginning of tradition.

Therefore rinascita, indeed, figures as a form of reconciliation between Vasari's two opposing concepts of time. Rebirth mediates between the unavoidable loss of origin and the potential for improvement inherent in time. The restoration of original artistic perfection permits this mediation as it coincides with the transformation of the past into the tradition of art. Thus, the transitoriness of time is disciplined by the constitution of an artistic heritage that provides the prerequisites for the continual work of improvement. The decline of art seems to be its destiny, for art has to dispose of its congenital defect by means of rebirth.

This initial defect is immediately linked to the fact that, in Vasari, it is the temporal difference between origin and imitation that represents the difference between God's creation and human art. Creation is still understood as being God's creation and, consequently, it has to be superior to all the works of art that mankind could ever have produced. Therefore, temporal distance reflects the indispensable inferiority of man to God, and the progression of time causes an increasing deterioration that the potential of gradual improvement -- being inherent in time as well -- could not overcome. Decline appears to be the price that had to be paid for the confirmation of God's superiority, which remained unavoidable, but at the same time, it prepares a rebirth that might permit the fate of decline to escape. The structural advantage of rebirth over origin lies in the fact that it is not the moment of creation but the initial perfection of human artists that is restored. Therefore, rebirth constitutes a strategy for escaping from the 
origin. It brings back the lost ability man acquired by imitating God's creation, but the act of creation itself is merely implied in regaining the ability to imitate it. Rebirth appears to be a kind of transformation of the origin into a technique of its own imitation by the establishment of tradition. For his rinascita Vasari cannot renounce a transcendent intervention, yet at the same time, this return to myth represents an attempt to eliminate it. From now on, the development of art will be one of its own perfection, for art is no longer compelled to bear the burden of its mythic origin.

\section{II}

The constitution of tradition will still be one of the essential characteristics of Michelet's concept of the Renaissance. The change in the status of tradition is already implied in the term 'Renaissance' itself. Vasari's use of the idea of rebirth takes recourse in myth precisely in order to escape its burden, the burden of origin. Instead of reclaiming a transcendent intervention, Michelet appeals to the historical connotations of the term rinascita. Transcendent assistance is supplanted by history itself and, simultaneously, history becomes a strategy of self-constitution. It is to observe that this selfreflectiveness of history originates in its mythical reinterpretation. The following phrase probably best reveals the fundamentally mythical character of history within Michelet's concept of the Renaissance: "Le XVIe siècle est un héros". The century is seen as a hero, the mythical interpretation of chronology and the respective formula appear to be emblematic of Michelet's concept of the Renaissance, that concept into which he transforms Vasari's idea of rinascita.

According to Michelet the functions the Renaissance has to fulfill, to a large extent, are due to the underlying concept of history. History is described in a particularly significant expression: Intelligence de la vie, "intelligence of life". History is a pattern of discovery. It aims at an investigation of life. Possibly, Michelet reveals a deep uncertainty about the nature of man by assigning to history an essentially heuristic function. If history is necessary to discover man's nature by means of empirical research, the traditional conception of nature has lost its liability. One of the main purposes of Michelet's understanding of the Renaissance is to resolve the contradiction between this traditional 
concept of nature and the historical reconstruction of a determinate identity of man, a history that, in turn, undermines that identity.

An initial approach to some essential features of Michelet's concept of history can be found in his expressive description of the end of the Middle Ages:

L'état bizarre et monstrueux, prodigieusement artificiel, qui fut celui du Moyen âge, n'a d'argument en sa faveur que son extrême durée, sa résistance obstinée au retour de la nature. Mais n'est-elle pas naturelle, dira-t-on, une chose qui, ébranlée, arrachée, revient toujours? La féodalité, voyez comme elle tient dans la terre. Elle semble mourir au XIIIe siècle, pour refleurir au XIVe. [...] Et le clergé, c'est bien pis. Nul coup n'y sert, nulle attaque ne peut en venir à bout. Frappé par le temps, la critique et le progrès des idées, il repousse toujours en dessous par la force de l'éducation et des habitudes. Ainsi dure le Moyen âge, d'autant plus difficile à tuer, qu'il est mort depuis longtemps. Pour être tué, il faut vivre. [ 4 ]

This short characterization of the Middle Ages contains more than Michelet's judgement on this period. As I mentioned above, it can be considered a key to his conception of history in general. Obviously, the relationship between nature and life constitutes the major problem of his study, and, indeed, this problem will definitely turn out to be the center of Michelet's theoretical framework. At the same time, the undeniable difficulties implied in the relationship between nature and culture are revealed here. Michelet's debt to the Enlightenment is still visible in his concept of a nature humaine based on reason and justice. Referring to the specific achievements of man in the Age of Renaissance, Michelet declares that "he has studied the deep fundamentals of his nature. He has begun to establish himself in Justice and Reason" ("Il a sondé les bases profondes de sa nature. Il a commencé à s'asseoir dans la Justice et la Raison"). The basic role of reason is not even limited to the nature of man, it represents the ground of nature in general:

Et alors, par l'imprimerie, se constitue le grand duel. D'une part, l'Antiquité grecque et romaine, si haute dans sa sérénité heroïque. D'autre part, l'Antiquité biblique, mystérieuse, pathétique et profonde. De quel côté penchera 
l'âme humaine? à qui sera la Renaissance? qui renaîtra des anciens dieux? L'arbitre est la Nature. Et celui-là serait vainqueur, à qui elle donnerait son sourire, son gage de jeunesse éternelle. [...] "Suis la nature." Ce mot des stoïciens fut l'adieu de l'Antiquité. "Reviens à la nature," c'est le salut que nous adresse la Renaissance, son premier mot. Et c'est le dernier mot de la Raison. [ $\underline{\mathbf{5}}$ ]

By assigning to Nature and Raison the role of an arbitrator, Michelet, at the same time, reveals a certain instability in the relationship between these two substantial categories and different historical cultures. The variability of cultural identity does not appear any more as a multiple representation of human nature. Nature and reason turn into arbitrators between competing cultural identities. It is highly significant, in this respect, that only print produces such a rivalry. But, regarded as an instrument for making present divergent historical cultures, print is nothing but a figuration of the archive, a metaphor of history itself. The mere transformation of nature and reason from a substance of human existence into an arbitrator between man's different cultural identities indicates the loss of importance of both categories in comparison with their central position in the philosophy of the Enlightenment. They do not guarantee the eternal truth of man any more, they turn into a distinctive feature of competing cultures. The mere transformation from substance to method, obviously, reveals the change in the status of both categories. Reason and nature are ultimately supplanted by history itself, and that most apparently demonstrates their fundamental loss of importance. For it is the factual success of ancient culture in the Renaissance, the fact of its growing significance in cultural self-description that offers Michelet the criterion for its naturalness. Thus, history becomes a kind of tribunal, and 'nature' is a mere supplementary predicate used to justify the course of history. Once more the Renaissance appears to be emblematic of Michelet's concept of history. If the historians in their search for the truth of man produce an archive of the past, the same effect is attributed, now, to the technique of print invented in that period, and the humanists' interest in classical antiquity is claimed as proof of the natural superiority of that culture. Thus, the Renaissance is even more than an emblem of history, it offers a solution to the crucial and, ultimately, unsolved problem of Michelet's idea of history: the determination of human nature notwithstanding the variability of man's forms of life. Nevertheless, the supposed naturalness of Greek 
and Roman culture is not founded on anything but its contingent historical success. The mere facts do not only substitute nature, they usurp its position.

By conferring the role of an arbitrator to nature and reason, Michelet already establishes an intimate relation between both categories and time. As I mentioned before, they have to justify the contingent course of history. But in the lines quoted above, Michelet seems, at first, to prefer another form of relating reason to time. Referring again to an Enlightenment idea, he proclaims his belief in progress, in the progrès des idées. Nevertheless, he has to concede the ineffectiveness of reason's battle against the well-established clergy representing, for him, the radical suppression of nature. For a long period, the struggle of nature itself does not succeed. The cause of the effective resistance of an unnatural culture against nature itself lies in the deep ambiguity of Michelet's conception of life. Obviously, life has to be considered as a part of nature, but, at the same time, life undermines the possibility of a determination of the nature of man. Although the Middle Ages seem to be an incarnation of the suppression of nature to Michelet, their energetic will to live also has to be called natural. It is for that reason that the nature of man is unable to overcome the power of life. Life here denotes a force of self-preservation, and its formal character, therefore, denies all conceptual determinations of nature. The example of scholasticism used by Michelet is apt to illustrate the basic contradiction between nature and life. Scholasticism, a genuine representative of the medieval hostility for nature, is equipped with great vitality, although its hostility for nature is part of its fundamental theoretical assumptions. Regarding the world as a mirroring of underlying ideas, scholasticism necessarily perverts nature. However, its vitality remains unbroken.

The example of scholasticism also reveals an aspect of Michelet's conception of nature, which decisively contributes to an explanation of its profound ambiguity. Obviously, his scathing attack on medieval philosophy represents, at the same time, a critique directed against a perversion of his own theoretical credo; his characterization of scholasticism offers a caricature of empirically based research. Instead of observing nature, medieval philosophy suppresses it. Thus, in Michelet's work, truth and nature appear to be a part of a specific theoretical program: they are objects of empirical research. The instability of both categories is essentially due to their theoretical status. Nature is an unknown and, therefore, an absent object that has to be brought 
to light by an empirical investigation. The properties of life, conceived as a dissimulated force, as an eminently effective power of self-preservation, seem to be a consequence resulting from one fundamental premise underlying all empirical research: the conceptual vagueness of its objects. It is only this uncertainty that generates the necessity for research. Hence, the substantial indifference of life towards the properties of beings, the negation of all differences between them, appears to be a concretization of the theoretical status that nature possesses for all empirical research: it represents its basic uncertainty. The characteristics of life seem to anticipate the assessment of the success of such research: The intention to determine the essence of nature is bound to fail because of a structural lack of substance in life.

The categorical ambiguity of nature, oscillating in Michelet between a universal concept of selfpreservation and a determinate semantic concept (as in the nature of man), can, at the same time, be described as a dissociation of nature from truth. More precisely, the relationship between both also becomes utterly ambivalent. On the one hand, nature is still regarded as an epistemic entity: it is an object of knowledge and, in the shape of reason, it constitutes the essence of man. This conception preserves a philosophical tradition that has always identified substance with thought. On the other hand, assuming the shape of life, a force of nature emerges that denies its alliance with thought and, therefore, destroys all difference. As a dynamic principle, life is immediately related to time, hence its affinity to history. Life is a force that confers the quality of duration to temporality. Yet, as a universal principle of preservation, it undermines all conceptual oppositions. Nevertheless, as life must undeniably be considered to be a part of nature, it also has to support the truth of man, and yet, at the same time, it denies all the distinctions that constitute his nature. These contradictions necessarily raise the question of their possible resolution in Michelet's conception of history. His answer is based on the interpretation of history conceived as a permanent struggle of life with itself, of an agon going on between the forces of truth and the forces aiming at its very destruction. Eventually, it is the dynamism inherent in life that produces this struggle, that transforms a basic logical contradiction into a mythical agon in which epochs figure as antagonists. Therefore, in the name of man's nature and truth, the Renaissance competes with the Middle Ages, which represent the oppression of the nature of man, an oppression, however, thatdoes not diminish his vitality at 
all. "Le XVIe siècle est un héros". "The sixteenth century is a hero": The mythical interpretation of chronology arises out of a conception of history that resolves the contradictory relationship between nature and life by transforming history into a struggle between both.

Nevertheless, the biological interpretation of history by means of its identification with life, the transformation of the vagueness of the nature of man into the contradictions inherent in life, only represents a part of the theoretical characteristics of history. It is, at the same time, symptomatic for Michelet's conception of history that the work of historians becomes indispensable even for the course of history itself. Thus, the naturalization of history conflicts with the interpretation of its course as an effect of historical research. This ambivalence is, particularly, mirrored in Michelet's uncertain judgement on the status of culture. On the one hand, culture bears a threatening affinity to death, because it is, by definition, opposed to nature and hence to life. Significantly, Michelet's strong criticism is mainly directed against one institution: school. His attack against school can be understood in as much as this institution constitutes, indeed, a counterconcept to natural life. By the formation of a tradition, it thwarts the logic of life and death, substituting preservation for procreation. School originates the artificial and hence a reprehensible life. Therefore, Michelet defined the Middle Ages as a substantially artificial epoch: "L'état bizarre et monstrueux, prodigieusement artificiel, qui fut celui du Moyen âge". At the same time, its artificiality serves to explain the - unnatural - duration of its existence. Having been dead for a long time, the Middle Ages nevertheless continue to exist, but not controlled by nature. But the essential ambivalence of all of Michelet's central categories in spite of its affinity to death, involves more or less, a positive function of culture, and its usefulness is mirrored in the relationship between history and historians. On the one hand, history creates an archive of the past and thus - just like school - it thwarts the logic of life. From that point of view, it unavoidably constitutes a risk. On the other hand, the work of historians is indispensable to the preservation of the nature of man, because only historians can defend it against its own destruction by time, and also against the ruinous effects of life. This contradiction arising between the res gestae and the historia rerum gestarum also characterizes the Middle Ages. Although the nature of man is suppressed by its institutions, man's loss of identity in this period is due to the forgetfulness of medieval culture, to a lack of historical memory: 
J'ai dit [...] à quel point le monde s'était oublié. Oublié naturellement, de lui-même et par le temps, par la négligence? Oh! non. On ne dira jamais, dans la vérité, la pénétrante blessure qui fendit le cœur de l'homme vers 1200, lui rompit sa tradition, brisa sa personnalité, et le sépara si bien de lui-même, que, si l'on parvient à lui retrouver quelque image de ce qu'il fut, il a beau y regarder, il dit: "Quel est cet homme-là?". [ $\underline{\mathbf{6}}$ ]

Although the nature of man is committed to the hand of life and, therefore, has to be protected from any artificial intervention in the natural course of life, the preservation of the identity of man needs memory, it needs the work of historians. Hence, the Middle Ages, blamed for a suppression of nature that is caused by its schools, are also criticized for their lack of tradition, for a forgetfulness that contributes decisively to the decline of man's identity. Again, the question of how Michelet succeeds in resolving these contradictions between the unnaturalness of any intervention in the course of life and the indispensability of the work of historians for the preservation of man's nature in history is raised. Once again the Age of Renaissance has to resolve these contradictions. The age of rebirth appears to be the Utopia of history, a period of reconciliation between the work of historians and the process of history, whose natural course develops and, at the same time, destroys the nature of man. The passage from the Middle Ages to the Renaissance does not merely represent one historical passage among others. On the contrary, it gains a crucial importance to the destiny of history itself, a conception of history that has submitted the truth of man both to the dynamics of life and to the historian's methodological concerns.

Born out of a precarious symbiosis between cultural restitution and natural rebirth, the Age of Renaissance unavoidably bears an utterly hybrid character. Michelet calls the 12th century an "Age de science et d'enfance à la fois" ("both an Age of science and of childhood"). It is the period that announces a new aeon's rise and the eventual defeat of the Middle Ages. If a hybridization of cultural restitution and natural rebirth, a mediation between incompatible conceptions form the programmatic nucleus in Michelet's conception of the Renaissance, consequently, the rhetorical strategies that he uses in order to characterize this period gain a particular importance. The following lines offer an example of a particularly vivid description of that epoch: 
[...]; l'Europe moderne revoyait sa mère, l'antiquité, et se jetait dans ses bras. L'Orient va se rapprocher tout à l'heure de l'Amérique. Spectacle digne de l'œil de Dieu! La famille humaine réunie, à travers les lieux et les temps, se regardant, se retrouvant, pleurant de s'être méconnue. Combien cette grande mère, la noble, la sereine, l'héroïque antiquité, parut supérieure à tout ce qu'on connaissait, quand on revit, après tant de siècles, sa face vénérable et charmante! "O mère! que vous êtes jeune! disait le monde avec des larmes, de quels attraits imposants nous vous voyons parée! Vous emportâtes au tombeau la ceinture éternellement rajeunissante de la mère d'amour... Et moi, pour un millier d'années, me voici tout courbé et déjà sous les rides." Il y eut là, en effet, un mystère amer pour l'humanité. Le nouveau se trouva le vieux, le ridé, le caduc. L'antiquité parut jeune et par son charme singulier, et par son accord parfait avec la science naissante. [ 7 ]

Michelet's skillful use of a technique of visualization does not only figure as a rhetorical method of persuasion. This technique in which he succeeds in reviving the discovery of Antiquity serves as an indispensable instrument for achieving the abovementioned symbiosis between cultural restitution and biological regeneration. The effect of the lines quoted here is produced, to a high degree, by the specific rhetorical concept on which it is built: it is in large part due to the figure of anagnorisis. This concept is particularly suitable for the purpose it serves because anagnorisis establishes a biological relationship between the person that discovers something he has lost and the object of this discovery. Anagnorisis is a form of recognition among members of the same family. However, anagnorisis is, generally, a part of a tragic plot, hence the scene described by Michelet, in a certain way, also bears a tragic impact. Such an effect is due to an apparent inversion of time: The son seems to be old; the mother seems to be young. Yet, at the same time, this is an effect of mere appearance. Thus, it is appearance which supplants biological substance.

The interpretation of the Renaissance as a universal program of history originates the unacceptability of Vasari's restriction of the rinascita to art. For Michelet, a model that proposes art as the beginning of man's rebirth, cannot offer more than a provisional solution. Since philosophy and theology, which would have been 
more suitable for the rediscovery of truth, had been controlled by the clergy, only artists could escape the tyranny of the Middle Ages. The loss of the importance of art in Michelet's conception of the Renaissance follows logically from the interpretation of this period as a reestablishment of truth. On the contrary, the crucial importance of art in Vasari's conception of rinascita is equally coherent, since for him rebirth is not a matter of truth, but a matter of perfection. Nevertheless, because of the basic ambiguity prevailing in Michelet's conception of history in general, even his idea of Renaissance does not permit the restriction of its achievements to an intellectual rediscovery of truth. The Age of Renaissance, it is true, offers the historian the model of a culture that discovers its own identity by means of archeology. But the naturalness of the Renaissance is due to the fact that it participates in life, in the mythical struggle between life's competing forces that constitutes the course of history. Hence, the rebirth of man, the eruption of a "sauvage énergie", becomes apparent only in an actual war. The "Introduction" of Michelet's volume La Renaissance, in fact, is a mere introduction in the full meaning of the term. Eventually, the scientific and artistic achievements that he describes in that part of his book, form a kind of introduction. All art and science that seal the end of the Middle Ages are nothing but preparations for an eruption of life. Thus, the mythical struggle which underlies life, actually comes to light in a political war. Therefore, after his "Introduction", Michelet begins the description of the real Renaissance by telling the story of Charles VIII' campaigns.

As I mentioned before, the difference between the respective conceptions of rebirth in the studies of Vasari and Michelet, is based upon a difference between truth and perfection. But perfection implies production, while truth, on the contrary, implies knowledge. Therefore, for Vasari, the establishment of a cultural tradition constitutes the creation of resources that permit the improvement of artistic production. But for Michelet, history represents a strategy aiming at the acquisition of knowledge about man; hence it threatens to reduce his freedom of action. Localizing the truth of man in the past threatens to transform the present time into a museum. Therefore, Michelet's definition of an age of rebirth, as he openly declares in his preface, also aims at a defense of man's freedom of action. The Age of Renaissance has to prove that the search for truth in the past does not contradict the simultaneous shaping of the future. Once more, the biological interpretation of history appears to be particularly suitable for that purpose although, at the 
same time, it originates undeniable risk: life comes to light in an effusion of violence. In the end, Michelet's "sauvage énergie" means nothing but physical superiority. Thus, the artistic creation of the Renaissance only serves to prepare an effusion of collective violence. Again, the basic ambiguity of Michelet's conception of history is mirrored in his description of the wars led by Charles VIII. The search for the truth of man by investigating the past is intimately related to the destruction of the past by physical violence. Perhaps, the hermeneutic usurpation of the past that inheres in Michelet's lecture of Vasari's Vite only presents a civilized - variety of unavoidable violence.

The alliance between truth and time, implied in this conception of history, structurally bears a risk in it, as, in these conditions, shaping the future always presupposes the destruction of the present, a destruction that has to be legitimized by a recourse to the past. It seems as if the humanistic discourses of today have drawn their conclusions from this conception of history and its dialectics of truth and life, taking into account its specific risks. The present interest in all forms of memory and archives assumes the form of a criticism of this very concept. This criticism is based upon a solid scepticism concerning the possibility of determining a definite truth of man, accompanied by the concern about the dangers inherent in all efforts to shape the future. To define culture as a work of memory certainly guarantees, to a higher degree, the absence of cultural violence. Nevertheless, this advantage, at the same time, represents an undeniable inconvenient, for the respective definition of culture appears to be an intentional retreat from all efforts to shape the future, an agnostical submission of the imagination of possible worlds to an uncontrolled - and hence dangerous "sauvage énergie". To contribute an answer to the unresolved problem of defining the relationship between the past and the future remains an important task for "humanistic discourses today".

Andreas Kablitz Cologne

\section{NOTES}

1. Giorgio Vasari, Le vite dei piú eccellenti pittori, scultori e architetti, a cura di Carlo L. Ragghianti, I, Milano/Roma 1947, p. 191 s.

2. Ibidem, p. 204. 
3. Ibidem, p. 213.

4. Jules Michelet, Histoire de France au seizième siècle, La Renaissance, Paris s. t., p. 9.

‥ Ibidem, p. 383.

6. Ibidem, p. 26. Cf., p. 25: "Inutile de dire que ces gens ne comprennent déjà plus rien à la forte et croyante époque dont ils délayent les ouvrages. Ils sont plus étrangers que nous à la vie des temps héroïques. Ils n'ont ni le temps ni le goût de connaître et d'étudier ces mœurs d'un âge voisin, mais complètement oublié. Ils prennent sans difficulté des noms de lieux pour des noms d'hommes, etc. etc.".

7. Ibidem, p. 291.

Accueil Surfaces | Table des matières | Recherche Surfaces Home Page | Table of Contents | Search

PUM | Livres | Revues | Publications électroniques | Vente et distribution 